\title{
Estonian oil shale power plants' ash handling problems
}

\author{
H. Arro, J. Loosaar, T. Pihu \& A. Prikk \\ Department of Thermal Engineering, \\ Tallinn University of Technology, Estonia
}

\begin{abstract}
Over $90 \%$ of the Estonian basic power supply is covered by oil shale-fired thermal power plants. Every year about 11 million tons of oil shale (ash content $45-47 \%$ ) is fired. The old pulverised firing (PF) and the new circulated fluidised bed (CFB) technologies are used. The PF boilers were commissioned between 1959 and 1973. Due to their age and problems relating to environmental and economical performance, two old blocks were replaced using the CFB technology. The new CFB units $(2 \times 215 \mathrm{MWel})$ delivered by Foster Wheeler started operation in 2003-2004 and are meeting the EU LCP Directive limits of gaseous emissions without any additional flue gas cleaning equipment.

The most serious problem today is ash handling. Power plants (PP) using big amounts of water for ash handling are not known in Europe and are environmentally hazardous. In compliance with the EU directives the oil shale power plants must be switched over to a technology which minimises high alkaline liquid waste (dry, semidry or dense slurry technology) from July 2009. Before taking a final decision, it has to be found out what might be involved in adopting the new technology and what problems might emerge. Whatever technology we use for ash removal, ash fields come into contact with millions of cubic metres of rainwater a year which becomes polluted. The question of how to neutralise free lime in oil shale ash as one of the most hazardous components seems to be a particularly important question.

This paper describes the problems relating to the chemical-mineralogical composition of oil shale ash. The conditions at hydro (wet), dry, or semidry ash removal are analysed.
\end{abstract}

Keywords: Estonian oil shale, pulverised firing, circulating fluidised bed combustion, emissions, land filling. 


\section{The environmental hazardousness of ash fields}

The oil shale ash from boilers is not toxic to nature as such. It has been proved by many studies and by the fact that the ash fields have spontaneously covered themselves with plants $[1,2]$. The certificate given by the Inspection Centre of the Plant Material of the Republic of Estonia confirms it officially [3]. The oil shale ash fertiliser meets the quality and safety requirements established by the Estonian standards about using fertilisers. Therefore oil shale ash could be used as an alkaline fertiliser for agricultural lands and for reducing soil acidity.

The main cause for environmental hazardousness of ash fields is the highly alkaline water used in transporting ash. That is the circulating water, the composition of which has formed over the time due to the repetitious contact with ash [4]. Although the ions that are found in that ash water are mainly the same as we find in nature, the high $\mathrm{pH}$ value (12-13) of that water makes it environmentally hazardous. Though the water used in the ash handling system circulates and in normal circumstances does not get out of the system, there is a possibility that in case of breakdown it can leak into nature and big amounts might bring about tremendous environmental pollution.

In sediment ponds of the oil shale PP ash fields the amounts of water are huge, reaching up to millions of cubic metres. Despite the fact that the ash binds water when stored $\left(\sim 0.6-0.7 \mathrm{~m}^{3}\right.$ per one ton of ash) and at the same time evaporation takes place, there might be cases when the amount of water in sediment ponds can increase to the extent that it would be absolutely necessary to let the excessive water flow into the Narva River, which always means getting a special permission and incurring a big pollution tax. It is the Balti Power Plant that has had many problems with excess water. The increase of water is usually caused by the amount of precipitation and is therefore tightly connected with weather conditions. In different years the Balti PP has let out up to 2 million cubic metres of water from its sediment ponds.

Proceeding from the long-term data provided in the Estonian Encyclopaedia about the average precipitation in the town of Narva $(584 \mathrm{~mm} / \mathrm{year})$ and the area of the ash fields and sediment ponds of the Balti PP $\left(\sim 10.65 \mathrm{~km}^{2}\right)$ one can state that the average amount of water that falls to the ash fields is about 6.2 million cubic metres per year. Here we have to note that the Estonian PP where the area of the ash field and the sediment pond are smaller (total $\sim 8.1 \mathrm{~km}^{2}$ ) and the amount of ash, which binds water, is more than twice higher compared to the Balti PP, has not had any problems with excess water.

On basis of the previous information it seems to be a most welcome solution to reduce or totally give up the use of water in ash handling systems. Transferring the oil shale PP into dry or semidry ash handling system will bring up several questions that need to be solved before taking any respective decisions. To take over foreign practice as an example might not, in case of oil shale with some of its special qualities, yield the expected results.

In order to understand what might come up in connection with switching over to different new ash handling technologies, let us look at some of these problems more closely. 


\section{Problems relating to the chemical-mineralogical composition of oil shale ash}

In the present discussion we have left out the problems that are connected with transportation and dissemination of bigger amounts of ash that come up at conventional coal or brown coal PP. There is no doubt that the problem is quite complicated. However, when we take examples from foreign practice some of these issues could still be solved.

In addition to the aforementioned problems, there might be some special problems connected with a big amount (average $20 \%)$ of free lime $\left(\mathrm{CaO}_{\text {free }}\right)$ in oil shale ash. In case of coal and brown coal ashes there is not that much of free lime, or if there is, we can speak of mostly many smaller amounts of ash than in case of oil shale (especially counted on $\mathrm{MJ}$ ). As free lime reacts to water (slaking takes place), the formed $\mathrm{Ca}(\mathrm{OH})_{2}$ is to some extent water-soluble $\left(\mathrm{Ca}(\mathrm{OH})_{2}\right.$ solubility product in water is $3.1 \cdot 10^{-5}$ at $25^{\circ} \mathrm{C}$ ). The aqueous solution, depending on the amount of water it is in contact with, may be highly alkaline and in addition to that a lot of heat is discharged at slaking. That might not cause big problems at small ash concentrations, e.g. when using oil shale ash as mineral fertiliser. However it might cause considerable problems at such big concentrations of oil shale ash we can see in ash fields.

Table 1: Chemical composition of the exploited ash field's sediment pond water.

\begin{tabular}{l|c|c}
\hline \multicolumn{1}{c|}{ Indicator } & Measure & Value \\
\hline $\mathrm{pH}$ & & $12.2-13$ \\
$\mathrm{Na}^{+}$ & $\mathrm{mg} / \mathrm{l}$ & $100-180$ \\
$\mathrm{~K}^{+}$ & $\mathrm{mg} / \mathrm{l}$ & $3000-4765$ \\
$\mathrm{Ca}^{2+}$ & $\mathrm{mg} / 1$ & $400-800$ \\
$\mathrm{NH}_{4}^{+}$ & $\mathrm{mg} / 1$ & $0-1$ \\
$\mathrm{Cl}^{-}$ & $\mathrm{mg} / 1$ & $720-1070$ \\
$\mathrm{SO}_{4}{ }^{2-}$ & $\mathrm{mg} / 1$ & $1043-2960$ \\
$\mathrm{OH}^{-}$ & $\mathrm{mg} / 1$ & $1037-1395$ \\
$\mathrm{CO}_{3}{ }^{2-}$ & $\mathrm{mg} / 1$ & $180-360$ \\
\hline
\end{tabular}

In oil shale PP ash fields where the stored ash contains big amounts of free lime or $\mathrm{Ca}(\mathrm{OH})_{2}$, it brings about the pollution of rainwater on the ash fields with $\mathrm{Ca}(\mathrm{OH})_{2}$ or other water-soluble ash components and such a rise of $\mathrm{pH}(\mathrm{pH} \geq 10)$ so that letting such water into nature is not allowed because of its environmental hazardousness. If circulating water gets into contact with fresh ash during a longer period as it happens in the oil shale PP at ash handling, the composition of dissolved salts will change as well. It happens because, in addition to $\mathrm{Ca}(\mathrm{OH})_{2}$, oil shale ash contains some other water-soluble salts like $\mathrm{K}_{2} \mathrm{SO}_{4}, \mathrm{KCl}, \mathrm{CaSO}_{4}$. 
The ion composition of the ash fields' water is not in accordance with the relative content of salt in oil shale ash, but rather with the chemical balance in the condition where salt solution (ash field water) is in continuous contact with ash. Quite remarkable is the fact that the potassium compounds content in the ash field water is high (Table 1 [4]).

On the basis of the above, we can note that, in case there is a wish to diminish the chemical impact of ash fields to the environment, we have to get rid of free lime in the ash. The simplest way to do it seems to be slaking the free lime in the stored oil shale ash and, in addition to that, re-carbonising it. Free in nature, limestone $\mathrm{CaCO}_{3}$ is nearly indecomposable and does not present any danger to nature. What would happen in the ash fields when no special measures were applied to bind free $\mathrm{CaO}$ ? To find it out, we have dealt with the issue from the point of view of different ash removal technologies.

\subsection{Conditions at hydro ash removal}

Presently no special measures for binding free $\mathrm{CaO}$ are applied to ash removal at our oil shale power plants. The ash, transported to the ash fields with a big amount of water (10-20 $\mathrm{m}^{3}$ for a ton of ash), is slaking in the process on its own accord. That slaking will take some time and may last for hours but the ash stored in the ash fields is under a constant flow of water.

The solubility of the formed $\mathrm{Ca}(\mathrm{OH})_{2}$ is determined by the conditions of the chemical balance and the amount of soluble $\mathrm{Ca}(\mathrm{OH})_{2}$ is not that big because the highly alkaline water used and circulating in the system for ash removal is previously more or less saturated with mineral salts. Therefore the produced $\mathrm{Ca}(\mathrm{OH})_{2}$ will mainly stay in the stored ash layers. As for the following carbonising by the agency of $\mathrm{CO}_{2}$, then as the research has shown [1,2], the ash in the ash fields does not bind $\mathrm{CO}_{2}$ from the air that much and it forms only $10-20 \%$ of the $\mathrm{CO}_{2}$ produced in boilers by the way of carbonate decomposition. It seems that the new layers cover the old ones quickly enough and it makes it difficult or impossible for the $\mathrm{CO}_{2}$ in the air to get into contact with ash and the potentially capable of reacting $\mathrm{Ca}(\mathrm{OH})_{2}$ in the ash cannot react to $\mathrm{CO}_{2}$. Access to the ash during its storing is prevented by the ash transporting water that covers the ash field area. Initially clean rainwater, after falling on the exploited ash fields, comes into contact with the ash transporting water and becomes polluted. Formed at such contact, $\mathrm{Ca}(\mathrm{OH})_{2}$ is able, as shown in the calculations of the Tallinn University of Technology's Department of Thermal Engineering (TUT's DTE), to pollute huge amounts of water - some hundred tons of ash may theoretically contaminate all rainwater falling onto the ash fields during the year. During that process no decrease of saltiness (dilution) due to the soluble components in the ash is taking place and because of the additional rainfall the balanced condition is being restored (depending on the weather conditions one can still see certain unbalance in the composition of ash field water [4]).

In the ash field areas which are not in use, $\mathrm{Ca}(\mathrm{OH})_{2}$ has been preserved in ash layers and these ash fields are probably potentially capable of changing rainwater into alkaline water. Because of the environment protection demands release of that polluted rainwater back into nature is impermissible. We have to state that it 
is only a presumption because at the present time we do not possess the exact data about rainwater pollution caused by ash fields. It might be probable that the amount of $\mathrm{Ca}(\mathrm{OH})_{2}$ and other soluble components in unused ash field areas is decreasing because of leaching to that extent that rainwater pollution will decrease or even stop if rainwater is unable to penetrate into inner layers because of their impermeability.

While there is a lot more water used in hydro ash removal than might evaporate or be bound by the ash, most of it drains into sediment ponds while flowing across the ash field surface. The ash particles get settled, according to their size and density, from the flow and are deposited on the ash field surface. In the given conditions the spreading of the ash on the ash field surface is more or less even and the formed ash layer is generally smooth, although at different places along the flow the granular composition is different. The big amount of water, which has a cooling effect, is the reason why the amount of heat produced during the slaking process of free lime is not able to raise the temperature of the system to that extent that the swelling caused by the temperature can influence the formation of ash layers. As we can find several components with binder properties in oil shale ash (like clinker minerals, among them puzzolans), which obtain binder properties when the compound contains $\left.\mathrm{Ca}(\mathrm{OH})_{2}\right)$, the deposited ash petrifies in a period of time, forming waterproof layers $[1,2,5]$. That will undoubtedly decrease the environmental hazardousness of ash fields because the contact of rainwater with the ash layers containing $\mathrm{Ca}(\mathrm{OH})_{2}$ is made more difficult.

\subsection{Conditions at dry or semidry ash removal}

Ash removal with a small amount of water has already been tested at the Balti PP. In fact, it was only an experiment where ash removal by the dense slurry technology, suggested by the Hungarian company EGI, was implemented. In this case the ratio of water and ash was $\sim 1: 1$. The result of that test allowed us to understand what will happen when the amount of water used in ash removal is decreased $[1,2]$.

First we have to mention that because of the small amount of water the flow of ash slurry across the ash field will get worse. In the situation where the most part of water in the slurry has either been bound by the ash or evaporated, so that the remaining ash-water mixture can be considered as a wet solid substance, the flow will stop completely. However it is clear that the amount of water has to be bigger than that bound by the ash (0.6-0.7 $\mathrm{m}^{3}$ to a ton of ash) and the amount evaporated during ash removal. In case of smaller amounts of water or dry ash handling it is better to use other methods (distribution piping allowing more uniform spreading of slurry, with the help of bulldozers, etc.).

There is another problem that arises in connection with small amounts of water. The amount of heat produced at free lime slaking is sufficiently high to raise the temperature of the stored ash and cause intensive cracking and knobbing of the surface of the ash field. We noticed the emergence of such big knobs on the surface of the ash field during the dense slurry tests $[1,2]$. At the same time, as the tests showed, the penetration of the $\mathrm{CO}_{2}$ from the air into the 
stored ash layer is not so intensive as to suffice to completely bind the $\mathrm{Ca}(\mathrm{OH})_{2}$ produced in the free lime slaking process and to turn into environmentally safe $\mathrm{CaCO}_{3}$. Therefore $\mathrm{Ca}(\mathrm{OH})_{2}$, with a strongly alkaline reaction, will stay in the ash field even in that case.

It seems impossible to manage ash storing without water even in case of dry ash handling. It will be too complicated to bind the stored ash into a monolithic mass without water. There might be a risk that a slightly stronger wind, if we take into account how fine the ash is, can cause a dust storm and the highly alkaline ash will be carried over the areas around the ash field causing their pollution. Mechanical compression of the layer would not help here either. The layers will swell and crack after a rainfall because of the reaction with the free lime. We also have to consider the fact that rainwater becomes polluted after its contact with alkaline compounds and other soluble compounds found in ash. How to mix ash and water and to spread the ash over the ash field is another question. Knowing that in case of oil shale ash we have to deal with enormous amounts of ash, it is not easy to find a practical solution to this problem. The problem will get even more serious when we want to turn free lime into $\mathrm{CaCO}_{3}$ in order to make free lime environmentally safe and to bind produced $\mathrm{CO}_{2}$ back as much as possible.

\section{Handling technologies of alkali water}

\subsection{Alkali ash water neutralisation by acids}

One possible solution to neutralise alkali components of water, as some companies dealing with ash field problems have initially suggested, is to use hydrochloric acid. However, that brings out the following questions:

1. the amount of acid needed;

2. the impact of $\mathrm{CaCl}_{2}$ in ash water on the environment.

As the theoretical calculations carried out by the TUT's DTE have shown, in order to neutralise the average $20 \%$ of free lime in ash we need about 0.6 tons of concentrated hydrochloric acid per 1 ton of ash. It means nearly 3 million tons of hydrochloric acid a year for the ash produced at Estonian oil shale PPs (a bit less than 5 million tons a year) at the present time. Using large amounts of hydrochloric acid at both power plants would mean equipping them with big acid managements. It would mean installing the necessary ash water neutralising equipment. The neutralisation of alkali water by acid is started at Estonian PPs.

The impact of the product of free lime neutralisation, $\mathrm{CaCl}_{2}$, on the environment is another question that needs attention. $\mathrm{CaCl}_{2}$ is a good watersoluble agent. Therefore we have to take into account that nearly all free lime found in ash will come into contact with the ash water as $\mathrm{CaCl}_{2}$ no matter what kind of water, either water for transporting ash or rainwater. It will certainly need some research in what way water polluted with $\mathrm{CaCl}_{2}$ will influence the environment, how much of it will be produced and what the level of pollution 
will be. According to the Estonian standard [6], drinking water may contain up to $350 \mathrm{mg} / \mathrm{dm}^{3}$ of chlorides.

\subsection{Alkaline ash water neutralisation by flue gases}

The goal of the technology is to use $\mathrm{CO}_{2}$ in flue gases for transforming $\mathrm{Ca}(\mathrm{OH})_{2}$ and $\mathrm{KOH}$ in the alkaline ash water into carbonates, harmless to the environment. This would also bring water's $\mathrm{pH}$ within the allowed limits $(\mathrm{pH} \leq 9)$. Practical tests of alkaline ash water neutralisation by flue gases have been carried out, but the water amounts neutralised were considerably smaller, at a coal power plant [7].

Below are reviewed the ash water neutralisation possibilities with oil shale boiler flue gases. The calculations were based on the average ash water data (Table 1). The $\mathrm{CO}_{2}$ amounts produced in boilers were calculated on the basis of the oil shale heating value and the extent of carbonate decomposition $\left(\mathrm{k}_{\mathrm{CO} 2}\right)$ as described in [8].

The components causing water alkalinity are $\mathrm{OH}^{-}$and $\mathrm{CO}_{3}{ }^{2-}$. The $\mathrm{Ca}(\mathrm{OH})_{2}$ and $\mathrm{KOH}$ neutralisation with $\mathrm{CO}_{2}$ can, depending on the reaction conditions, take place with the formation of either carbonates or bicarbonates. $\mathrm{Ca}\left(\mathrm{HCO}_{3}\right)_{2}$ (bicarbonate) is well soluble in water while $\mathrm{CaCO}_{3}$ belongs to the substances that are hardly soluble in water. To prevent the emergence of carbonaceous precipitants in the device and the connection pipes, such a regime must be preferred that results in the formation of bicarbonates.

The neutralisation of the $\mathrm{OH}^{-}$ions found in water and the transformation of carbonates into bicarbonates take place in accordance with the following equations:

$$
\begin{gathered}
\mathrm{OH}^{-}+\mathrm{CO}_{2} \rightarrow \mathrm{HCO}_{3}^{-} \\
\mathrm{CO}_{3}{ }^{2-}+\mathrm{H}_{2} \mathrm{O}+\mathrm{CO}_{2} \rightarrow 2 \mathrm{HCO}_{3}{ }^{-}
\end{gathered}
$$

As the above provided reaction equations demonstrate, one mole of $\mathrm{CO}_{2}$ is required to neutralise each gram-ion found in water that causes alkalinity $\mathrm{OH}^{-}$ and $\mathrm{CO}_{3}{ }^{2-}$ ion.

Proceeding from the data shown in Table 1 concerning the average $\mathrm{OH}^{-}$and $\mathrm{CO}_{3}{ }^{2-}$ content in ash water, the stoichiometric amount of $\mathrm{CO}_{2}$ needed to neutralise every cubic metre of ash water is $\sim 76$ moles.

When $1 \mathrm{~kg}$ of oil shale, with the heating value of $8.4 \mathrm{MJ} / \mathrm{kg}$, is combusted in a boiler, the estimated amount of $\mathrm{CO}_{2}$ produced is $\sim 20.5 \mathrm{moles} / \mathrm{kg}$ [8]. Thus, the stoichiometric amount of $\mathrm{CO}_{2}$ obtained from combusting 1 ton of oil shale would be sufficient to neutralise approximately $270 \mathrm{~m}^{3}$ of ash water.

On the basis of the data quoted in [9] that approximately $10 \%$ of $\mathrm{CO}_{2}$ fed into the scrubbers is engaged in the reaction, the neutralised amount of water would on average comprise $27 \mathrm{~m}^{3}$ per ton of combusted oil shale.

Such application of flue gases enables neutralisation of thousands of cubic metres of ash water per hour at oil shale power plants. One additional useful effect is the decreased $\mathrm{CO}_{2}$ emission. 


\section{Necessary investigations}

As a lot of necessary data to solve the questions relating to the ash removal technology is missing yet, it is obvious that preliminary research is needed. What kind of questions need to be looked at, depends mostly on the ash removal methods to be applied. Apparently it would be wise approximately to decide on the planned technology in general and then evaluate which final solutions of technological problems need additional data and what would that be. The main problems that should most probably be considered, in addition to those concerning the ash transport, as are follows:

- how to influence the ash stored in the ash fields to form a strong and uniform mass;

- how (by means of which technology) to achieve a sufficiently intensive binding of $\mathrm{Ca}(\mathrm{OH})_{2}$ produced in free lime slaking process to $\mathrm{CO}_{2}$ in order to get environmentally safe $\mathrm{CaCO}_{3}$;

- which other methods could be used to neutralise $\mathrm{Ca}(\mathrm{OH})_{2}$ (e.g. with the help of acids or $\mathrm{CO}_{2}$ from flue gas) and what the used technology could be and how environment friendly would the products be;

- to what extent the ash field surface will pollute rainwater if it does not get into contact with the ash-transporting water (in unused ash fields or their parts).

There will certainly be a lot more questions that need to be answered, depending on the used ash removal technology, when the actual process starts. It is impossible to bring them out here. The further choice of research work will depend on the chosen ash removal technology.

Nevertheless, we have to bear in mind that, in case of Estonian oil shale, the main questions will be relating to the free lime in ash.

On the basis of everything that has been said above it is clear that if a tender bidding is announced to the companies to transfer the oil shale power plants to dry or semidry ash removal, a clause will have to be added in the project task about solving the problems, among others, connected with free lime.

Without solving these questions it would be impossible to develop an environmentally satisfactory project for Estonian oil shale.

\section{Summary and conclusions}

To sum up the ideas given above we can say that moving over to a dry or semidry ash removal is not enough to raise the safety of the environment. To get even a least satisfactory result we will have to solve a lot of fairly complicated problems, which are strictly relating to ash removal. To achieve the environmentally safe conditions, we have to find a solution to the question how to neutralise free lime in oil shale ash as one of the most hazardous components. The amount of water needed for ash removal does not play an important role here. Whatever technology we use for ash removal, ash fields come into contact with millions of cubic metres of rainwater a year which becomes polluted to such 
an extent, due to the soluble components found in ash field material, that letting it out into nature will be inconceivable because of the environmental requirements.

\section{References}

[1] Arro, H., Prikk, A., Pihu, T. Decreasing the environmental hazard of ash fields of the Balti power plant. Keskkonnatehnika. 4/02, pp. 41-44, 2002. (In Estonian)

[2] Arro, H., Prikk, A., Pihu, T., Reducing the environmental hazardousness of ah fields. Symposium on oil shale, 18-21 November 2002, Tallinn, Estonia. P. 7.

[3] Certificate of Estonian Inspection Centre of the Plant Material. CS 003697 11.09.2000 (In Estonian)

[4] Oil Shale Ash. Success through experience. The positive result of 35 years' use in industry and agriculture. Eesti Energia, AS Narva Elektrijaamad.

[5] Civil and Environmental Engineering Test Equipment. $9^{\text {th }}$ Edition Catalogue. ELE International Ltd, England.

[6] Estonian standard EVS 663:1995. Drinking water. General requirements.

[7] A circulating system of hydro ash removal with a node for neutralising the clarified water with flue gases. All-Union Scientific Research Institute of B. E. Vedeneyev // L., 1990 (In Russian)

[8] Arro, H., Prikk, A., Pihu, T. Calculation of qualitative and quantitative composition of Estonian oil shale and its combustion products. Part 1. Calculation on the basis of heating value // Fuel, Vol 82/18, pp 2179-2195, 2003.

[9] Chemical and energy industry specialist's reference book. Volume 1. Edited by V. A. Golubtsov et al. Gosenergoizdat, M-L., 1960, 327 pages. (In Russian) 